\title{
HIV-1 tropism testing and clinical management of CCR5 antagonists: Quebec review and recommendations
}

\author{
Cécile Tremblay $\mathrm{MD}^{1,2}$, Isabelle Hardy $\mathrm{PhD}^{1,3}$, Richard Lalonde $\mathrm{MD}^{4,5}$, Benoit Trottier MD ${ }^{1,5,6}$, Irina Tsarevsky BSc ${ }^{5,7}$, \\ Louis-Philippe Vézina MSc ${ }^{5,8}$, Michel Roger MD PhD ${ }^{1,3}$, Mark Wainberg PhD ${ }^{9,10}$, Jean-Guy Baril MD ${ }^{1,5,11}$
}

C Tremblay, I Hardy, R Lalonde, et al. HIV-1 tropism testing and clinical management of CCR5 antagonists: Quebec review and recommendations. Can J Infect Dis Med Microbiol 2013;24(4):202-208.

HIV-1 tropism assays play a crucial role in determining the response to CCR5 receptor antagonists. Initially, phenotypic tests were used, but limited access to these tests prompted the development of alternative strategies. Recently, genotyping tropism has been validated using a Canadian technology in clinical trials investigating the use of maraviroc in both experienced and treatment-naive patients. The present guidelines review the evidence supporting the use of genotypic assays and provide recommendations regarding tropism testing in daily clinical management.

Key Words: CCR5; HIV; Maraviroc; Tropism

The discovery of the C-C chemokine receptor type 5 (CCR5) and I C-X-C chemokine receptor type 4 (CXCR4) chemokine receptors as coreceptors for HIV binding and viral entry into the host cell has significantly improved our knowledge of HIV pathogenesis, including primary HIV infection and the course of disease progression. The concurrent identification of viral populations with different cell tropisms paved the way for the development of a new class of antiretrovirals: CCR5 coreceptor antagonists. The determination of HIV viral tropism is even more relevant because this class of molecules is effective only against viruses that use the CCR5 coreceptor, also known as $\mathrm{R} 5$ viruses.

The purpose of the present review, which is targeted to health care professionals, is to describe the different methods assessing HIV-1 coreceptor tropism and to define the pertinence of such tests in a clinical setting. Given the constant evolution of HIV tropism assays, future assay developments will likely lead to modifications of the recommendations provided in the present article.

\section{METHODS}

A literature review of published scientific articles and abstracts presented at international conferences before February 20, 2013, was performed using the following key words: "maraviroc", "vicriviroc" and "CCR5". The literature was screened by an HIV expert panel. Five face-to-face meetings occurred between members of the panel. Articles were analyzed based on their relevance to the use of phenotypic and genotypic tropism tests. Group members also reviewed articles regarding the emergence of drug resistance in the past two years. Each recommendation was agreed on by consensus among clinicians and virologists. The resulting document was then approved

\section{Les tests de détermination du tropisme du VIH-1 et la prise en charge clinique des antagonistes du CCR5 : une analyse au Québec et des recommandations}

Les tests de détermination du tropisme du VIH-1 jouent un rôle capital dans la détermination de la réponse aux antagonistes des récepteurs du CCR5. Au début, on utilisait des tests phénotypiques, mais leur accès limité a suscité l'élaboration d'autres stratégies. Récemment, le génotypage du tropisme a été validé à l'aide d'une technologie canadienne, dans le cadre d'essais cliniques faisant appel au maraviroc tant chez des patients déjà en traitement que chez des patients naïfs au traitement. Les présentes lignes directrices passent en revue les données probantes en appui à l'utilisation de tests génotypiques et contiennent des recommandations au sujet des tests de détermination du tropisme dans la prise en charge clinique quotidienne.

by the Advisory Committee on the Clinical Management of People Living with HIV.

Each recommendation is identified, according to a classification code that was adapted from the Panel on Antiretroviral Guidelines for Adults and Adolescents (1), using a letter (A to C) followed by a Roman numeral (I to III) separated by a hyphen. The letter corresponds to the strength of the recommendation, evaluated by the experts of the Advisory Committee, whereas the Roman numeral refers to the grounds for the recommendation (Table 1).

\section{STATE OF KNOWLEDGE AND BACKGROUND}

Viral entry into the cell involves several inter-related steps The attachment and entry of HIV-1 to $\mathrm{CD}^{+}$lymphocytes involve several steps that are all potential targets for antiretroviral therapy (2). The glycoproteins that form the HIV-1 envelope, namely glycoprotein (gp) 120 and gp41, exist as trimeric complexes on the surface of the virion and serve as mediators, both for the attachment of the virus to the target cell as well as for the fusion of the viral and cell membranes (3). For the HIV-1 membrane to fuse with the target cell, gp120 must first bind to the CD4 receptor. This binding results in a conformational change of the gp120 protein, which exposes a high-affinity binding site for a chemokine receptor on the surface of the cell (CCR5 or CXCR4). This site is a conserved region of gp120 on the bridging sheet between two domains of the protein, near the V3 loop. The binding of gp120 to the coreceptor induces other conformational changes resulting in the activation of gp41. The fusion peptide, located at the $\mathrm{N}$-terminal region of gp 41 , is exposed and penetrates the membrane of the target cell. This structure, composed of three helices, folds back on itself to form a six-helix bundle, thereby resulting

${ }^{1}$ Centre hospitalier de l'Université de Montréal; ${ }^{2}$ Laboratoire de santé publique du Québec; ${ }^{3} \mathrm{HIV}$ Genotyping Program; ${ }^{4}$ McGill University Health Centre; ${ }^{5}$ Advisory Committee on the Clinical Management of Persons Living with HIV; ${ }^{6}$ Clinique médicale l'Actuel; 7 Service de lutte contre les infections transmissibles sexuellement et par le sang, ministère de la Santé et des Services sociaux; ${ }^{8}$ Programme national de mentorat sur le VIHsida; ${ }^{9} \mathrm{McGill}$ AIDS Centre; ${ }^{10} \mathrm{McGill}$ University, Montreal, Quebec; ${ }^{11}$ Clinique médicale du Quartier Latin

Correspondence: Dr Cécile Tremblay, Laboratoire de santé publique du Québec, 20045, chemin Ste-Marie, Ste-Anne-de-Bellevue,

Québec H9X 3R5. Telephone 514-457-2070, ext 235, fax 514-457-6346, e-mail c.tremblay@umontreal.ca 
in the apposition of the viral and cellular membranes that enables virus entry into the host cell (4-11). Several coreceptors involved in HIV entry into the cell have been identified in vitro; nonetheless, only CCR5 and CXCR4 have a clinical significance in vivo.

\section{Viral tropism may vary during disease progression}

The viral strains isolated at the onset of HIV infection easily infect macrophages and primary lymphocytes, but are unable to infect immortalized T cell lines. These strains are known as M-tropic. At a later infection stage, it is possible to isolate more cytopathic variants that have acquired the ability to replicate in cell lines, such as H9 and MT-2, but can no longer replicate in macrophages. Such viruses are termed T-tropic. Because viral replication in such cell lines causes cytopathic effects and the formation of syncitium, these viral strains are called syncytium inducing (SI). In comparison, M-tropic viral strains that do not form syncytium are termed non-SI (NSI). Following the discovery of CCR 5 and CXCR4 chemokine receptors and their role in HIV cell entry, it was observed that SI viruses preferentially used the CXCR4 coreceptor whereas NSI used the CCR5 coreceptor. Viruses using the CXCR4 coreceptor to enter the cell are referred to as X4 viruses whereas those using the CCR5 coreceptor are referred to as $\mathrm{R} 5$ viruses. The term 'R5/X4 dual-tropic' describes a single virus using both coreceptors, whereas mixed tropic defines a population of viruses, some of which use CCR 5 and others that use CXCR4. Thus, in a tropism assay, a population of viruses could exhibit dual and/or mixed tropism, termed D/M-tropic (12). Non-R5 tropism determined by genotype has been associated with a greater mean CD4 decrease in antiretroviral-naive patients (13). Both antiretroviral-naive and -experienced patients infected with $\mathrm{X} 4$ viruses are more likely to have advanced HIV-1 disease (CD4 cell count $<200$ cells $/ \mathrm{mm}^{3}$ ) (14). In patients receiving first-line antiretroviral therapy (atazanavir/ritonavir or nevirapine plus tenofovir/emtricitabine), viral tropism was observed to be independently associated with virological response, but not CD4 cell count recovery at week 24 (15). In nontreated patients, the time to clinical progression did not differ between patients infected with R5 or X4 viruses (16). Therefore, it may not be useful to determine coreceptor tropism at the time of diagnosis to decide when to start antiretroviral therapy. Throughout the course of antiretroviral treatment, viral tropism can evolve and patients can experience a tropism switch (17). Although most individuals are infected by R5 viruses, the error-prone reverse transcriptase coupled with the immune selective pressures quickly lead to the emergence of viral quasispecies, among which some may have a different cell tropism (18). Recent data suggest that there may be differences in tropism distribution among HIV-1 subtypes (19). The overall prevalence of X4 viruses is only approximately $16 \%$, and is significantly higher in antiretroviral-experienced than antiretroviral-naive patients $(20,21)$. However, several studies have confirmed that, at an advanced stage of the disease, X4 viral strains or strains that can use both coreceptors are found in approximately $50 \%$ of HIV-infected individuals (22-33). Newer and more sensitive assays to characterize viral tropism have shown that X4 or D/Mtropic strains can be present early in the course of HIV infection, but at a very low level $(12,34,35)$. The factors leading to a transition from R5 to X4 viral population during the course of disease have yet to be determined. Moreover, we do not know whether this transition is responsible for a more aggressive form of the illness or if it simply reflects the availability of certain target cells (36). In this respect, the determination of viral tropism is not recommended for predicting the natural evolution of the disease (C-III) (16).

Nevertheless, determination of viral tropism is essential for predicting the response to treatment with CCR5 antagonists. These molecules, which bind to the CCR5 coreceptor and block the interaction with gp120, are efficacious only in individuals infected with R5 viruses. Indeed, data from phase II/III clinical trials in which the CCR5 antagonists maraviroc (MVC) or vicriviroc were used have demonstrated that the detection of $\mathrm{D} / \mathrm{M}$-tropic strains at study onset was associated with a
TABLE 1

Recommendation classification code

\begin{tabular}{ll}
\hline Recommendation strength \\
\hline A & Strong recommendation \\
B & Moderate recommendation \\
C & Optional recommendation \\
Recommendation grounds \\
\hline I & At least one randomized placebo-controlled clinical trial \\
II & Clinical trials without placebo-control, case-control studies or \\
& prospective surveys \\
III & Expert opinion
\end{tabular}

Adapted from reference 1

poorer response to treatment $(12,37)$. The double-blind Maraviroc versus Efavirenz in Treatment-Naive Patients (MERIT) study compared MVC with efavirenz in 720 antiretroviral-naive patients. The underestimation of minority $\mathrm{X} 4$ or $\mathrm{D} / \mathrm{M}$-tropic viral strains before MVC treatment led to excessive virological failures in this arm compared with the efavirenz arm. At week 48, MVC did not meet the noninferiority criterion of $<50$ copies $/ \mathrm{mL}$ ( $65.3 \%$ for MVC versus $69.3 \%$ for efavirenz) at a threshold of $-10 \%$. Following a post hoc analysis that excluded $15 \%$ of patients with non-R 5 screening virus by current, more sensitive tropism assays, the final conclusions of the study were modified and noninferiority was demonstrated $(38,39)$.

It is important to note that it is possible for HIV to develop resistance to MVC in the absence of a tropism change; thus, a tropism assay performed after treatment failure may not necessarily be adequate to indicate that CCR5 antagonists will be active in a given patient (40). Currently, MVC is the only CCR 5 antagonist that has been approved by Health Canada for clinical use (41-44). Other CCR5 antagonists are under development. It is essential to be able to adequately determine viral tropism before treatment with CCR5 antagonists to ensure the best possible use of our therapeutic arsenal.

\section{TROPISM ASSAYS}

Both phenotypic and genotypic assays to assess HIV-1 tropism are available. Each testing method has its distinct advantages and inconveniences. Clinical trials investigating coreceptor antagonists have relied on phenotypic assays, which are costly, complex and time consuming. Moreover, they typically require a minimum viral load of 1000 copies $/ \mathrm{mL}$, which excludes patients with recent virological failure who have a low viral load as well as patients for whom a change in therapy could be considered for tolerability reasons despite their undetectable viral load (12). It is possible to determine coreceptor usage from HIV DNA when the viral load is below the limit of detection, although the clinical utility of this test has yet to be established $(45,46)$.

Genotypic assays are faster and less costly. The challenge that both phenotypic and genotypic assays share is their ability to detect minority viral populations that are clinically significant.

\section{Phenotypic assays}

The first generation of phenotypic tests were based on the detection of syncytium formation by HIV-1 on MT-2 cells. More recent phenotypic tests detect viral infection of cell lines that specifically express the CD4 receptor, and the CCR5 or CXCR4 coreceptors.

MT-2 assay: The MT-2 assay evaluates the capacity of HIV-1 isolates to induce (or not) the formation of syncytium in an in vitro model. The correlation between SI phenotype and X4 coreceptor usage is not perfect and this test is not commonly used in clinical practice.

Phenotypic assays of coreceptor usage: The purpose of phenotypic assays using the coreceptor is to evaluate viral infection in cell lines that express either CCR5 or CXCR4 coreceptor exclusively. To this end, a recombinant virus that expresses the HIV envelope amplified from a patient's plasma is produced, and its capacity to infect cells expressing the CD4 receptor as well as the CCR5 or the CXCR4 coreceptor is observed using reporter genes that express a luminescent signal, such as luciferase (12). 
The phenotypic test that is most commonly used in practice, and that was the benchmark test in CCR 5 antagonist clinical trials, is the Enhanced Sensitivity Trofile Assay (ESTA, Monogram Biosciences Inc, USA). It is considered to be the gold standard phenotypic assay for HIV tropism determination (47). The ESTA uses the type of pseudovirus described above and U87:CXCR4 and U87:CCR5 cells. The samples producing a luminescent signal only on CCR5 cells are characterized as R5, those that produce a signal only on CXCR4 cells are characterized as $\mathrm{X} 4$, and those that produce a luminescent signal on both cell lines are $\mathrm{D} / \mathrm{M}$-tropic. Moreover, the test is validated by using coreceptor antagonists specific to each cell type to block HIV entry. The original Trofile assay reliably detected X4 variants present in mixed virus populations of R5 and X4 variants only if they represented at least $10 \%$ of the total viral population (12). The capacity of the assay to detect minority X4 populations is clinically significant. Four cohorts involving CCR 5 antagonists using this test to identify R5 viruses have demonstrated that $9 \%$ to $26 \%$ of the samples initially labelled as R5 were, in fact, D/M-tropic (48). The patients for whom these minority populations were poorly identified did not respond as well to treatment and experienced more virological failures (38). Thus, the ESTA is a more sensitive version of the original Trofile test. This test has been shown to detect minority populations present at levels of $0.3 \%$ of the viral population in in vitro studies (49). Nevertheless, its sensitivity on clinical samples varies according to the viral load and other factors $(12,47,50)$.

\section{Genotypic assays}

Genotypic assays for determining HIV-1 tropism are based on the sequencing of the V3 loop, which contains the key determinants of viral tropism. It is known that several V3 loop residues are important for coreceptor usage. In fact, the presence of positively charged amino acids in positions 11 and 25, commonly known as the 11/25 rule, associated with an electrical charge of the V3 loop greater than +5 , enables the prediction of CXCR4 tropism with $90 \%$ sensitivity in in vitro clones (51-53). The performance of this rule in clinical samples is expected to be lower. Nonetheless, this rule has a lower than $60 \%$ sensitivity for predicting CXCR4 usage, because other amino acids in the V3 loop also play a role in tropism $(36,54-66)$. Furthermore, isolates using the same coreceptor can have a highly variable $\mathrm{V} 3$ sequence $(4,67-75)$. Although the V3 loop sequence of gp120 is the main determinant for viral tropism, it appears that other regions of this glycoprotein can intervene in the binding to the coreceptor, such as the V1/V2/V4/V5, C1, C2, C3 and C4 regions (76-78). Thus, it has been reported that V1/V2 mutations, in the absence of a change in V3, frequently increased the capacity of the virus to use CCR5, but were, however, unable to confer CXCR4 use. Finally, certain changes in gp41 can also influence tropism; nonetheless, the incorporation of these mutations in the interpretation models did not improve their predictive value (79-84).

The interpretation of these sequences relies on bioinformatic algorithms based on several variables: the known genotype/phenotype associations, the electrical charge of the various amino acids and the clinical variables (nadir CD4 and viral load) in particular. Examples of these bioinformatic tools include geno2pheno [coreceptor] (http:// coreceptor.bioinf.mpi-inf.mpg.de/) and the position-specific scoring matrices (http://indra.mullins.microbiol.washington.edu/webpssm/). Moreover, it has been demonstrated that the interpretation parameter of geno2pheno [coreceptor], called False Positive Rate (FPR) (which determines the probability of falsely classifying an R5 virus as X4), should be set at a value between $5 \%$ and $10 \%$ to avoid false classification of X4 strains as R5 (85); more sensitive methodologies may be more valuable when population sequencing yields a FPR $>20 \%$ to improve the accuracy of identifying X4 variants (86).

Phenotypic and genotypic assays were compared, along with their clinical outcomes, to validate their use. Thus, the availability of frozen plasma collected as part of MVC clinical trials allowed two retrospective evaluations of subjects included in the MERIT, MOTIVATE and
1029 trials $(85,87,88)$. These studies demonstrated that genotypic assays (on plasma viral RNA, triplicate sequencing) predicted the virological results in a similar way that the Trofile test did in antiretroviral-experienced patients (MOTIVATE trial [87]) and corroborated the ESTA test in treatment-naive patients (MERIT trial $[85,88])$. The results from these retrospective studies, as well as other prospective studies (89-91), have led several experts to state that genotypic tests developed according to certain parameters (described below) are adequate for predicting tropism during routine clinical testing (92). Duplicate PCR amplification and bulk sequencing have been shown to improve the sensitivity and specificity of population genotyping (93). In addition, genotypic testing in triplicate can improve X4 tropism prediction in individual cases (94). The performance of genotypic assays in 10 European laboratories was evaluated in a pairwise comparison (95). The concordance rates between the Trofile assay and genotypic assays were $89 \%$ for B subtypes and $79 \%$ for non-B subtypes. In a more recent retrospective analysis of Study A4001078, 91.7\% concordance (FPR 5.75\%) was observed between ESTA and population-based genotyping (96).

A genotypic assay based on ultra-deep sequencing (UDS) of the V3 loop was used in an attempt to detect minority X4 populations with a higher sensitivity $(97,98)$. This technology allows for the sequencing, from a patient sample, of thousands of different viral clones based on a sophisticated system of DNA capture on microscopic beads. The test is able to identify the selection of X4/R5 variants earlier in experienced patients being treated with a CCR5 antagonist (MOTIVATE study [97]), but not in treatment failure. In this study, the UDS tests and original Trofile test produced concordant results. More recently, the UDS assay demonstrated concordance with the ESTA assay for screening tropism assessments $(96,99)$ and for predicting short-term virological response as a function of tropism status in treatment-experienced patients in the MOTIVATE and A4001029 trials (100). The UDS assay was also able to distinguish between responders and nonresponders of MRV in a reanalysis of antiretroviral-naive patients in the MERIT trial (99). This analytical method is now used clinically at several sites. The majority of published studies of UDS tropism have used the 454 Life Sciences platform (454 Life Sciences/Roche, USA); however, three other platforms have also demonstrated similar concordance with virological response in comparison with the ESTA assay; namely, Illumina (Illumina Inc, USA), PacBio RS (Pacific Biosciences, USA) and Ion Torrent (Ion Torrent/Life Technologies, USA) (101). All of these platforms detected non-R5 variants at similar levels. Several studies are underway to determine the threshold of the minority variants that predict virological failure.

\section{Proviral DNA}

To date, assays for determining HIV-1 tropism have been performed on circulating viral strains (plasma RNA), which implies the existence of a replicating virus. In the event that we would want to use a CCR5 antagonist in a patient whose viral load has been completely suppressed (eg, treatment change as a result of poor tolerability), some suggest using proviral DNA integrated in peripheral blood mononuclear cells to determine whether the patient has been a carrier of X4 strains in the past (102-106). Numerous studies have compared the genotype of the proviral DNA with the genotype of plasma RNA before the start of treatment. The concordance of the results varied from $74 \%$ to $95.2 \%(102,106-108)$. A recent study used quantitative deep sequencing to demonstrate concordance between the genotypic tropism test on the pretreatment plasma RNA and the proviral DNA in patients who initiated antiretroviral treatment without a CCR5 antagonist and who had an undetectable viremia for at least two years (109). These results indicated that there was no evidence of X4 virus evolution in patients' sustained undetectable viremia. The concordance in R5 tropism between HIV-RNA (ESTA) and HIV-DNA provirus at the start of MRV therapy ranged between $71 \%$ and $85 \%$ $(106,110,111)$. Differences between the circulating quasispecies and the proviral compartment could be observed in some patients, as part 
of a comparison between the UDS technology and the original Trofile test (112). Therefore, these differences imply that the threshold used to classify a virus with an X4 tropism must be better defined when a technology as sensitive as the UDS is used. Although tropism tests on proviral DNA can be useful for identifying carriers of X4 strains, the correlation with response to treatment based on a CCR5 antagonist has never been demonstrated.

\section{RECOMMENDATIONS}

Based on the existing data, the HIV expert panel has issued the following recommendations:

1. A tropism assay must be performed before treatment initiation with a CCR5 receptor antagonist. This test should be performed four to six weeks before treatment initiation (A-I).

2. A tropism assay can be performed in case of treatment failure with a CCR5 receptor antagonist (B-II).

3. Determining the viral tropism is not recommended to predict the natural evolution of disease (C-III).

4. A V3 loop genotypic test performed on the plasma viral RNA should be used to assess viral tropism, as a result of its availability and its greater technical ease (B-II).

5. Use of a phenotypic assay should be possible in the event that repeated amplification for genotyping cannot be performed (A-I for the use of phenotypic assay in general; C-III for this subpopulation).

6. A tropism assay can be performed on proviral DNA when the viral loads are $<400$ copies $/ \mathrm{mL}$ and in the presence of limited therapeutic options. Nevertheless, the use of a CCR 5 receptor antagonist based on this test has yet to be validated by clinical trials in patients with suppressed viral load or who are experiencing therapeutic failure (C-III).

\section{REFERENCES}

1. Panel on Antiretroviral Guidelines for Adults and Adolescents. Guidelines for the use of antiretroviral agents in HIV-1-infected adults and adolescents. <www.aidsinfo.nih.gov/ContentFiles/ AdultandAdolescentGL.pdf $>$ (Accessed August 3, 2012).

2. Doms RW. Unwelcome guests with master keys: How HIV enters cells and how it can be stopped. Top HIV Med 2004;12:100-3.

3. Kwong PD, Wyatt R, Robinson J, Sweet RW, Sodroski J, Hendrickson WA. Structure of an HIV gp120 envelope glycoprotein in complex with the CD4 receptor and a neutralizing human antibody. Nature 1998;393:648-59.

4. Kwong PD. Human immunodeficiency virus: Refolding the envelope. Nature 2005;433:815-6.

5. Labrosse B, Treboute C, Brelot A, Alizon M. Cooperation of the $\mathrm{V} 1 / \mathrm{V} 2$ and $\mathrm{V} 3$ domains of human immunodeficiency virus type 1 gp120 for interaction with the CXCR4 receptor. J Virol 2001;75:5457-64.

6. Moore JP, Stevenson M. New targets for inhibitors of HIV-1 replication. Nat Rev Mol Cell Biol 2000;1:40-9.

7. Sackett K, Wexler-Cohen Y, Shai Y. Characterization of the HIV N-terminal fusion peptide-containing region in context of key gp41 fusion conformations. J Biol Chem 2006;281:21755-62.

8. Steger HK, Root MJ. Kinetic dependence to HIV-1 entry inhibition. J Biol Chem 2006;281:25813-21.

9. Wu L, Gerard NP, Wyatt R, et al. CD4-induced interaction of primary HIV-1 gp120 glycoproteins with the chemokine receptor CCR-5. Nature 1996;384:179-83.

10. Wyatt R, Kwong PD, Desjardins E, et al. The antigenic structure of the HIV gp120 envelope glycoprotein. Nature 1998;393:705-11.

11. Zhang W, Canziani G, Plugariu C, et al. Conformational changes of gp120 in epitopes near the CCR5 binding site are induced by CD4 and a CD4 miniprotein mimetic. Biochemistry 1999;38:9405-16.

12. Whitcomb JM, Huang W, Fransen S, et al. Development and characterization of a novel single-cycle recombinant-virus assay to determine human immunodeficiency virus type 1 coreceptor tropism. Antimicrob Agents Chemother 2007;51:566-75.

\section{CONCLUSION}

The viral tropism assay is an essential tool for ensuring the adequate use of CCR5 receptor antagonists. This new class of molecules has been used successfully in clinical trials involving patients experiencing treatment failures as well as treatment-naive patients. Reports on the use of these molecules to replace a treatment that has been interrupted as a result of intolerance in patients with a controlled viral load are only anecdotal, but trials are currently being conducted with genotype testing on proviral DNA to validate this clinical indication. Access to genotype testing for HIV-1 tropism is essential for the management of patients who will be prescribed a CCR5 receptor antagonist and this access must be supported. The laboratory techniques used to assess HIV-1 tropism are constantly evolving and the validation of genotypic assays as well as new technologies such as UDS must continue.

ACKNOWLEDGEMENTS: The authors gratefully thank the other members of the Advisory Committee on the Clinical Management of Persons Living with HIV: P Côté MD ${ }^{1,2,3}$, P Junod MD4, N Lapointe MD B Lessard MD ${ }^{1,2,6}, \mathrm{~K}$ Monteith ${ }^{7}$, A Piché $\mathrm{MD}^{8}$, D Rouleau $\mathrm{MD}^{2}$, J Sousa ${ }^{9}$, $\mathrm{R}$ Therrien B Pharm $\mathrm{MSc}^{2}$, S Trottier $\mathrm{MD}^{10}$ and $\mathrm{C}$ Tsoukas $\mathrm{MD}^{11}$. They also thank the Réseau Sida et Maladies infectieuses of the FRQ-S for support to the genomic infrastructure, Anne Vassal for English translation of this document and Niamh Higgins for assisting with the revisions of this document. ${ }^{1}$ Clinique médicale du Quartier Latin; ${ }^{2}$ Centre hospitalier de l'Université de Montréal; ${ }^{3}$ Programme national de mentorat sur le VIH/ sida; ${ }^{4}$ Clinique médicale l'Actuel; ${ }^{5}$ Centre hospitalier universitaire SainteJustine; ${ }^{6}$ College of Family Physicians of Canada; ${ }^{7}$ Coalition des organismes communautaires québécois de lutte contre le sida (COCQ-sida); ${ }^{8}$ Centre hospitalier de l'Université de Sherbrooke; ${ }^{9}$ Comité provincial sur les traitements; ${ }^{10} \mathrm{Centre}$ hospitalier universitaire de Québec; ${ }^{11} \mathrm{McGill}$ University Health Centre.
13. Nozza S, Canducci F, Galli L, et al. Viral tropism by geno2pheno as a tool for predicting CD4 decrease in HIV-1-infected naive patients with high CD4 counts. J Antimicrob Chemother 2012;67:1224-7.

14. Santoro MM, Armenia D, Fabeni L, et al. The lowest X4 Geno2Pheno false-positive rate is associated with greater CD4 depletion in HIV-1 infected patients. Clin Microbiol Infect 2012;18:E289-98.

15. Seclen E, Soriano V, Gonzalez MM, et al. Impact of baseline HIV-1 tropism on viral response and CD4 cell count gains in HIV-infected patients receiving first-line antiretroviral therapy. J Infect Dis 2011;204:139-44.

16. Soulie C, Charpentier C, Flandre P, et al. Natural evolution of $\mathrm{CD}^{+}$cell count in patients with CD4 $>350$ or $>500$ cells $/ \mathrm{mm}^{3}$ at the time of diagnosis according to HIV-1 coreceptor tropism. J Med Virol 2012;84:1853-6.

17. Charpentier C, Joly V, Larrouy L, et al. Role and evolution of viral tropism in patients with advanced HIV disease receiving intensified initial regimen in the ANRS 130 APOLLO trial. J Antimicrob Chemother 2013;68:690-6.

18. Scarlatti G, Tresoldi E, Bjorndal A, et al. In vivo evolution of HIV-1 co-receptor usage and sensitivity to chemokine-mediated suppression. Nat Med 1997;3:1259-65.

19. Obermeier M, Berg T, Braun P, et al. Genotypic HIV-coreceptor tropism testing with geno2pheno[coreceptor]: Differences in prediction depending on HIV-1 subtype (Abst). 10th European Meeting on HIV \& Hepatitis Treatment Strategies \& Antiviral Drug Resistance. Barcelona, March 28 to 30, 2012.

20. Seclén E, Soriano V, Gonzalez M, Gomez S, Thielen A, Poveda E. Prevalence of X4-tropic viruses in HIV-1-infected patients according to CD4 counts, viral load and antiretroviral exposure (Abst). 6th International AIDS Society Conference on HIV Pathogenesis, Treatment and Prevention. Rome, July 17 to 20, 2011.

21. Seclén E, Soriano V, González M, et al. Prevalence of R5-tropic viruses in a large cohort of HIV-1 patients: Which are the current determinants of viral tropism? (Abst). XIX International AIDS Conference. Washington DC, July 22 to 27, 2012. 
22. Esbjornsson J, Mansson F, Martinez-Arias W, et al. Frequent CXCR4 tropism of HIV-1 subtype A and CRF02_AG during latestage disease - indication of an evolving epidemic in West Africa. Retrovirology 2010;7:23.

23. Frange P, Galimand J, Goujard C, et al. High frequency of X4/ $\mathrm{DM}$-tropic viruses in PBMC samples from patients with primary HIV-1 subtype-B infection in 1996-2007: The French ANRS CO06 PRIMO Cohort Study. J Antimicrob Chemother 2009;64:135-41.

24. Goetz MB, Leduc R, Kostman JR, et al. Relationship between HIV coreceptor tropism and disease progression in persons with untreated chronic HIV infection. J Acquir Immune Defic Syndr 2009;50:259-66

25. Huang W, Toma J, Stawiski E, et al. Characterization of human immunodeficiency virus type 1 populations containing CXCR4using variants from recently infected individuals. AIDS Res Hum Retroviruses 2009;25:795-802.

26. Hunt PW, Harrigan PR, Huang W, et al. Prevalence of CXCR4 tropism among antiretroviral-treated HIV-1-infected patients with detectable viremia. J Infect Dis 2006;194:926-30.

27. Kassaye S, Johnston E, McColgan B, Kantor R, Zijenah L, Katzenstein D. Envelope coreceptor tropism, drug resistance, and viral evolution among subtype C HIV-1-infected individuals receiving nonsuppressive antiretroviral therapy. J Acquir Immune Defic Syndr 2009;50:9-18.

28. Melby T, Despirito M, Demasi R, Heilek-Snyder G, Greenberg ML, Graham N. HIV-1 coreceptor use in triple-class treatmentexperienced patients: Baseline prevalence, correlates, and relationship to enfuvirtide response. J Infect Dis 2006;194:238-46.

29. Moreno S, Clotet B, Sarria C, et al. Prevalence of CCR5-tropic HIV-1 among treatment-experienced individuals in Spain. HIV Clin Trials 2009;10:394-402.

30. Saracino A, Monno L, Cibelli DC, et al. Co-receptor switch during HAART is independent of virological success. J Med Virol 2009;81:2036-44.

31. Shepherd JC, Jacobson LP, Qiao W, et al. Emergence and persistence of CXCR4-tropic HIV-1 in a population of men from the multicenter AIDS cohort study. J Infect Dis 2008;198:1104-12.

32. Simon B, Grabmeier-Pfistershammer K, Rieger A, Sarcletti M, Schmied B, Puchhammer-Stockl E. HIV coreceptor tropism in antiretroviral treatment-naive patients newly diagnosed at a late stage of HIV infection. Aids 2010;24:2051-8.

33. Waters L, Mandalia S, Randell P, Wildfire A, Gazzard B, Moyle G. The impact of HIV tropism on decreases in CD4 cell count, clinical progression, and subsequent response to a first antiretroviral therapy regimen. Clin Infect Dis 2008;46:1617-23.

34. Coakley E, Petropoulos CJ, Whitcomb JM. Assessing chemokine co-receptor usage in HIV. Curr Opin Infect Dis 2005;18:9-15.

35. Wilkin TJ, Su Z, Kuritzkes DR, et al. HIV type 1 chemokine coreceptor use among antiretroviral-experienced patients screened for a clinical trial of a CCR5 inhibitor: AIDS Clinical Trial Group A5211. Clin Infect Dis 2007;44:591-5.

36. Rosen O, Sharon M, Quadt-Akabayov SR, Anglister J. Molecular switch for alternative conformations of the HIV-1 V3 region: Implications for phenotype conversion. Proc Natl Acad Sci U S A 2006;103:13950-5.

37. Su Z, Gulick RM, Krambrink A, et al. Response to vicriviroc in treatment-experienced subjects, as determined by an enhancedsensitivity coreceptor tropism assay: Reanalysis of AIDS clinical trials group A5211. J Infect Dis 2009;200:1724-8.

38. Cooper DA, Heera J, Goodrich J, et al. Maraviroc versus efavirenz, both in combination with zidovudine-lamivudine, for the treatment of antiretroviral-naive subjects with CCR5-tropic HIV-1 infection. J Infect Dis 2010;201:803-13.

39. Sierra-Madero J, Di Perri G, Wood R, et al. Efficacy and safety of maraviroc versus efavirenz, both with zidovudine/lamivudine: 96-week results from the MERIT study. HIV Clin Trials 2010;11:125-32.

40. Parra J, Portilla J, Pulido F, et al. Clinical utility of maraviroc. Clin Drug Investig 2011;31:527-42.

41. De Clercq E. Emerging anti-HIV drugs. Expert Opin Emerg Drugs 2005;10:241-73.

42. Dorn CP, Finke PE, Oates B, et al. Antagonists of the human CCR5 receptor as anti-HIV-1 agents. Part 1: Discovery and initial structure-activity relationships for 1-amino-2-phenyl-4-(piperidin-1-yl) butanes. Bioorg Med Chem Lett 2001;11:259-64.
43. Strizki JM, Tremblay C, Xu S, et al. Discovery and characterization of vicriviroc (SCH 417690), a CCR5 antagonist with potent activity against human immunodeficiency virus type 1 . Antimicrob Agents Chemother 2005;49:4911-9.

44. Strizki JM, Xu S, Wagner NE, et al. SCH-C (SCH 351125), an orally bioavailable, small molecule antagonist of the chemokine receptor CCR5, is a potent inhibitor of HIV-1 infection in vitro and in vivo. Proc Natl Acad Sci U S A 2001;98:12718-23.

45. Toma J FA, Cook J, Martin J, Deeks S, Petropoulos C, Huang W. Phenotypic determination of HIV-1 coreceptor tropism using cellassociated DNA derived from blood samples (Abst). 17th Conference on Retroviruses and Opportunistic Infections. San Francisco, February 16 to 19, 2010.

46. Bellecave P, Paredes R, Anta L, et al. Determination of HIV-1 tropism from proviral HIV-1 DNA in patients with suppressed plasma HIV-1 RNA using population based-and deep-sequencing: Impact of X4-HIV variants on virologic responses to maraviroc? Antivir Ther 2012;17(Suppl 1):A53.

47. Reeves J, Coakley E, Petropoulos C, Whitcomb J. An enhancedsensitivity Trofile HIV coreceptor tropism assay for selecting patients for therapy with entry inhibitors targeting CCR5: A review of analytical and clinical studies. J Viral Entry 2009;3:94-102.

48. Wilkin TJ, Goetz MB, Leduc R, et al. Reanalysis of coreceptor tropism in HIV-1-infected adults using a phenotypic assay with enhanced sensitivity. Clin Infect Dis 2011;52:925-8.

49. Trinh L, Han D, Huang W, et al. Technical validation of an enhanced sensitivity Trofile HIV coreceptor tropism assay for selecting patients for therapy with entry inhibitors targeting CCR5. Antivir Ther 2008;13(Suppl 3):A128.

50. Coakley E, Reeves JD, Huang W, et al. Comparison of human immunodeficiency virus type 1 tropism profiles in clinical samples by the Trofile and MT-2 assays. Antimicrob Agents Chemother 2009; 53:4686-93.

51. Dybowski JN, Heider D, Hoffmann D. Prediction of co-receptor usage of HIV-1 from genotype. PLoS Comput Biol 2010;6:e1000743.

52. Jensen MA, van 't Wout AB. Predicting HIV-1 coreceptor usage with sequence analysis. AIDS Rev 2003;5:104-12.

53. Low AJ, Swenson LC, Harrigan PR. HIV coreceptor phenotyping in the clinical setting. AIDS Rev 2008;10:143-51.

54. Briggs DR, Tuttle DL, Sleasman JW, Goodenow MM. Envelope V3 amino acid sequence predicts HIV-1 phenotype (co-receptor usage and tropism for macrophages). AIDS 2000;14:2937-9.

55. Chesebro B, Wehrly K, Nishio J, Perryman S. Mapping of independent V3 envelope determinants of human immunodeficiency virus type 1 macrophage tropism and syncytium formation in lymphocytes. J Virol 1996;70:9055-9.

56. Cocchi F, DeVico AL, Garzino-Demo A, Cara A, Gallo RC, Lusso P. The V3 domain of the HIV-1 gp120 envelope glycoprotein is critical for chemokine-mediated blockade of infection. Nat Med 1996;2:1244-7.

57. Huang W, Frantzell A, Toma J, et al. Defining evolutionary pathways and genetic barriers to cxcr4-mediated entry by HIV type-1. Antivir Ther 2010;15:A19.

58. Hung CS, Vander Heyden N, Ratner L. Analysis of the critical domain in the V3 loop of human immunodeficiency virus type 1 gp120 involved in CCR5 utilization. J Virol 1999;73:8216-26.

59. Kim FM, Kolson DL, Balliet JW, Srinivasan A, Collman RG. V3-independent determinants of macrophage tropism in a primary human immunodeficiency virus type 1 isolate. J Virol 1995;69:1755-61.

60. Kirchhoff F, Mori K, Desrosiers RC. The "V3" domain is a determinant of simian immunodeficiency virus cell tropism. J Virol 1994;68:3682-92.

61. Li Y, Rey-Cuille MA, Hu SL. N-linked glycosylation in the V3 region of HIV type 1 surface antigen modulates coreceptor usage in viral infection. AIDS Res Hum Retroviruses 2001;17:1473-9.

62. Napier KB, Wang ZX, Peiper SC, Trent JO. CCR5 interactions with the variable 3 loop of gp120. J Mol Model 2007;13:29-41.

63. Stamatatos L, Cheng-Mayer C. Structural modulations of the envelope gp120 glycoprotein of human immunodeficiency virus type 1 upon oligomerization and differential V3 loop epitope exposure of isolates displaying distinct tropism upon virion-soluble receptor binding. J Virol 1995;69:6191-8. 
64. Svicher V, Alteri C, Artese A, et al. Specific genetic signature in $\mathrm{V} 3$ base can modulate coreceptor usage in vivo, the interaction with neutralizing antibodies and HIV-1 cytopathic effect. Antivir Ther 2010;15:A20.

65. Xiao L, Owen SM, Goldman I, et al. CCR 5 coreceptor usage of non-syncytium-inducing primary HIV-1 is independent of phylogenetically distinct global HIV-1 isolates: Delineation of consensus motif in the V3 domain that predicts CCR-5 usage. Virology 1998;240:83-92.

66. Jensen MA, van 't Wout A. Predicting HIV-1 coreceptor usage with sequence analysis. AIDS Rev 2003;5:104-12.

67. Cho MW, Lee MK, Carney MC, Berson JF, Doms RW, Martin MA. Identification of determinants on a dualtropic human immunodeficiency virus type 1 envelope glycoprotein that confer usage of CXCR4. J Virol 1998;72:2509-15.

68. Choe H, Farzan M, Sun Y, et al. The beta-chemokine receptors CCR 3 and CCR 5 facilitate infection by primary HIV-1 isolates. Cell 1996;85:1135-48.

69. Hatziioannou T, Cowan S, Von Schwedler UK, Sundquist WI, Bieniasz PD. Species-specific tropism determinants in the human immunodeficiency virus type 1 capsid. J Virol 2004;78:6005-12.

70. Ikeda Y, Ylinen LM, Kahar-Bador M, Towers GJ. Influence of gag on human immunodeficiency virus type 1 species-specific tropism. J Virol 2004;78:11816-22.

71. Ly A, Stamatatos L. V2 loop glycosylation of the human immunodeficiency virus type 1 SF162 envelope facilitates interaction of this protein with CD4 and CCR 5 receptors and protects the virus from neutralization by anti-V3 loop and anti-CD4 binding site antibodies. J Virol 2000;74:6769-76.

72. Morikita T, Maeda Y, Fujii S, Matsushita S, Obaru K, Takatsuki K. The V1/V2 region of human immunodeficiency virus type 1 modulates the sensitivity to neutralization by soluble CD4 and cellular tropism. AIDS Res Hum Retroviruses 1997;13:1291-9.

73. Ogert RA, Lee MK, Ross W, Buckler-White A, Martin MA, Cho MW. N-linked glycosylation sites adjacent to and within the V1/V2 and the V3 loops of dualtropic human immunodeficiency virus type 1 isolate DH12 gp120 affect coreceptor usage and cellular tropism. J Virol 2001;75:5998-6006.

74. Vella C, King D, Zheng NN, Fickenscher H, Breuer J, Daniels RS. Alterations in the V1/V2 domain of HIV-2CBL24 glycoprotein 105 correlate with an extended cell tropism. AIDS Res Hum Retroviruses 1999;15:1399-402.

75. Yang ZY, Chakrabarti BK, Xu L, et al. Selective modification of variable loops alters tropism and enhances immunogenicity of human immunodeficiency virus type 1 envelope. J Virol 2004;78:4029-36.

76. Pastore C, Nedellec R, Ramos A, Pontow S, Ratner L, Mosier DE. Human immunodeficiency virus type 1 coreceptor switching: V1/V2 gain-of-fitness mutations compensate for V3 loss-of-fitness mutations. J Virol 2006;80:750-8.

77. Svicher V, Chen M, Alteri C. Key genetic elements in HIV-1 gp120 V1, V2 and C4 domains tightly and differentially modulate gp120 interaction with the CCR5 and CXCR4 $\mathrm{N}$ terminus and HIV-1 antigenic potential. Antivir Ther 2011;16:A14.

78. Monno L, Saracino A, Scudeller L, et al. Impact of mutations outside the V3 region on coreceptor tropism phenotypically assessed in patients infected with HIV-1 subtype B. Antimicrob Agents Chemother 2011;55:5078-84.

79. de Silva UC, Warachit J, Sattagowit N, et al. Genotypic characterization of HIV type 1 env gp160 sequences from three regions in Thailand. AIDS Res Hum Retroviruses 2010;26:223-7.

80. Huang W, Toma J, Fransen S, et al. Coreceptor tropism can be influenced by amino acid substitutions in the gp 41 transmembrane subunit of human immunodeficiency virus type 1 envelope protein. J Virol 2008;82:5584-93.

81. McNicholas P, Wei Y, Whitcomb J, et al. Characterization of emergent HIV resistance in treatment-naive subjects enrolled in a vicriviroc phase 2 trial. J Infect Dis 2010;201:1470-80.

82. Pfaff JM, Wilen CB, Harrison JE, et al. HIV-1 resistance to CCR5 antagonists associated with highly efficient use of CCR 5 and altered tropism on primary $\mathrm{CD} 4^{+} \mathrm{T}$ cells. J Virol 2010;84:6505-14.

83. Sterjovski J, Roche M, Churchill MJ, et al. An altered and more efficient mechanism of CCR 5 engagement contributes to macrophage tropism of CCR5-using HIV-1 envelopes. Virology 2010;404:269-78.
84. Thielen A, Lengauer T, Swenson L, et al. Mutations in gp41 are correlated with coreceptor tropism but do not improve prediction methods substantially. Antivir Ther 2011;16:319-28.

85. McGovern RA, Dong W, Zhong X, et al. Population-based sequencing of the V3-loop is comparable to the enhanced sensitivity Trofile assay in predicting virologic response to maraviroc of treatment-naive patients in the MERIT trial (Abst). 17th Conference on Retroviruses and Opportunistic Infections. San Francisco, February 16 to 19, 2010.

86. Svicher V, Cento V, Rozera G, et al. The genotypic false positive rate determined by $\mathrm{V} 3$ population sequencing can predict the burden of HIV-1 CXCR4-using species detected by pyrosequencing. PLoS One 2013;8:e53603.

87. McGovern RA, Thielen A, Mo T, et al. Population-based V3 genotypic tropism assay: A retrospective analysis using screening samples from the A4001029 and MOTIVATE studies. AIDS 2010;24:2517-25.

88. McGovern RA, Thielen A, Portsmouth S, et al. Population-based sequencing of the V3-loop can predict the virological response to maraviroc in treatment-naive patients of the MERIT trial. J Acquir Immune Defic Syndr 2012;61:279-86.

89. Macartney M, Cameron J, Strang A, et al. Use of a genotypic assay for prediction of HIV-1 coreceptor tropism and guiding the use of CCR 5 antagonists in clinical practice. Rev Antivir Ther Infect Dis 2010;1:42.

90. Obermeier M, Carganico A, Bieniek B, et al. Genotypic tropism testing from proviral DNA - test characteristics and clinical outcome. Antivir Ther 2010;15:A132.

91. Obermeier M, Carganico A, Bieniek B, et al. Update on the Berlin Maraviroc cohort - genotypic tropism testing results and therapeutic outcome at weeks 12 and 24. HIV Med 2009;10:67.

92. Harrigan PR, Geretti AM. Genotypic tropism testing: Evidence-based or leap of faith? AIDS 2011;25:257-64.

93. Raymond S, Recordon-Pinson P, Saliou A, et al. Improved V3 genotyping with duplicate PCR amplification for determining HIV-1 tropism. J Antimicrob Chemother 2011;66:1972-5.

94. Symons J, Vandekerckhove L, Paredes R, et al. Impact of triplicate testing on HIV genotypic tropism prediction in routine clinical practice. Clin Microbiol Infect 2012;18:606-12.

95. Sierra S BM, Zazzi M, Sönnerborg A, et al. Pairwise comparison of genotypic coreceptor tropism prediction between one reference center and 10 European laboratories. Antivir Ther 2010;15:A22.

96. Portsmouth S, Valluri SR, Daumer M, et al. Correlation between genotypic (V3 population sequencing) and phenotypic (Trofile ES) methods of characterizing co-receptor usage of HIV-1 from 200 treatment-naive HIV patients screened for Study A4001078. Antiviral Res 2013;97:60-5.

97. Swenson LC, Mo T, Dong WW, et al. Deep sequencing to infer HIV-1 co-receptor usage: Application to three clinical trials of maraviroc in treatment-experienced patients. J Infect Dis 2011;203:237-45.

98. Swenson LC, Moores A, Low AJ, et al. Improved detection of CXCR4-using HIV by V3 genotyping: Application of populationbased and "deep" sequencing to plasma RNA and proviral DNA. J Acquir Immune Defic Syndr 2010;54:506-10.

99. Swenson LC, Mo T, Dong WW, et al. Deep V3 sequencing for HIV type 1 tropism in treatment-naive patients: A reanalysis of the MERIT trial of maraviroc. Clin Infect Dis 2011;53:732-42.

100. Kagan RM, Johnson EP, Siaw M, et al. A genotypic test for HIV-1 tropism combining Sanger sequencing with ultradeep sequencing predicts virologic response in treatment-experienced patients. PLoS One 2012;7:e46334.

101. Archer J, Weber J, Henry K, et al. Use of four next-generation sequencing platforms to determine HIV-1 coreceptor tropism. PLoS One 2012;7:e49602.

102. Prosperi MC, Bracciale L, Fabbiani M, et al. Comparative determination of HIV-1 co-receptor tropism by Enhanced Sensitivity Trofile, gp120 V3-loop RNA and DNA genotyping. Retrovirology 2010;7:56.

103. Soulie C, Fourati S, Lambert-Niclot S, et al. Factors associated with proviral DNA HIV-1 tropism in antiretroviral therapy-treated patients with fully suppressed plasma HIV viral load: Implications for the clinical use of CCR 5 antagonists. J Antimicrob Chemother 2010;65:749-51

104. Verhofstede C, Vandekerckhove L, Eygen VV, et al. CXCR4-using HIV type 1 variants are more commonly found in peripheral blood 
mononuclear cell DNA than in plasma RNA. J Acquir Immune Defic Syndr 2009;50:126-36.

105. Svicher V, Alteri C, Montano M, et al. Performance of genotypic tropism testing on proviral DNA in clinical practice: Results from the DIVA study group. New Microbiol 2012;35:17-25.

106. Verhofstede C, Brudney D, Reynaerts J, et al. Concordance between HIV-1 genotypic coreceptor tropism predictions based on plasma RNA and proviral DNA. HIV Med 2011;12:544-52.

107. Bellecave P, Paredes R, Soriano V, et al. Determination of HIV-1 tropism from proviral HIV-1 DNA in patients with suppressed plasma HIV-1 RNA and its impact on virologic responses to maraviroc (Abst). 19th Conference on Retroviruses and Opportunistic Infections. Seattle, March 5 to 8, 2012.

108. Paar C, Geit M, Stekel H, Berg J. Genotypic prediction of human immunodeficiency virus type 1 tropism by use of plasma and peripheral blood mononuclear cells in the routine clinical laboratory. J Clin Microbiol 2011;49:2697-9.

109. Pou C, Codoñer F, Thielen A, et al. Plasma and PBMC viruses provide equivalent genetic information for genotypic tropism testing: Analysis using quantitative deep HIV-1 sequencing (Abst). 18th Conference on Retroviruses and Opportunistic Infections. Boston, February 27 to March 2, 2011.

110. Baroncelli S, Galluzzo CM, Weimer LE, et al. Evolution of proviral DNA HIV-1 tropism under selective pressure of maraviroc-based therapy. J Antimicrob Chemother 2012;67:1479-85.

111. Chapman D, Lie Y, Paquet A, et al. Tropism determinations derived from cellular DNA or plasma virus compartments are concordant and predict similar maraviroc treatment outcomes in an antiretroviral treatment experienced cohort (Abst). XIX International AIDS Conference. Washington DC, July 22 to 27, 2012.

112. Abbate I, Rozera G, Tommasi C, et al. Analysis of co-receptor usage of circulating viral and proviral HIV genome quasispecies by ultra-deep pyrosequencing in patients who are candidates for CCR5 antagonist treatment. Clin Microbiol Infect 2011;17:725-31. 


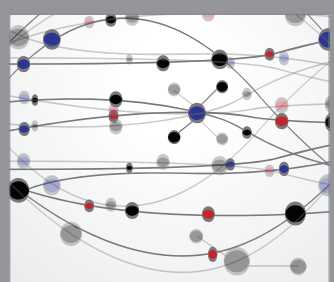

The Scientific World Journal
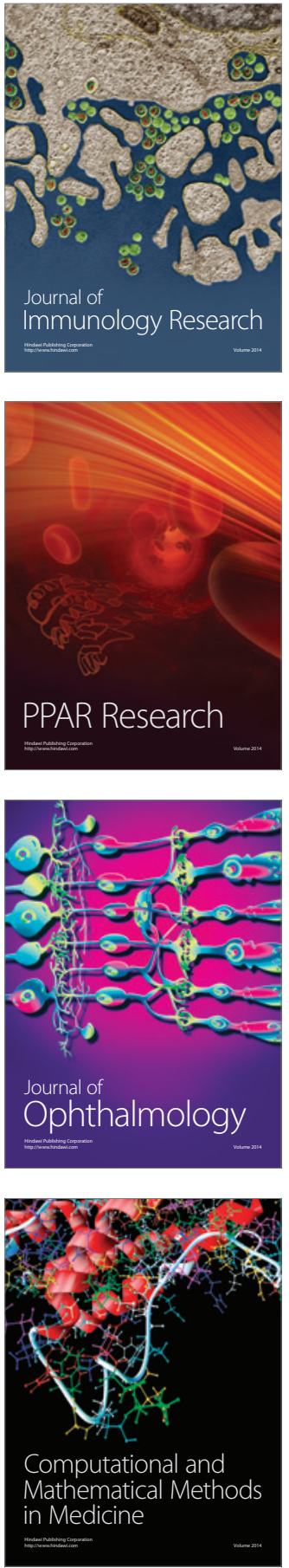

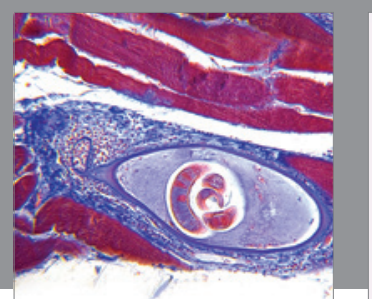

Gastroenterology Research and Practice

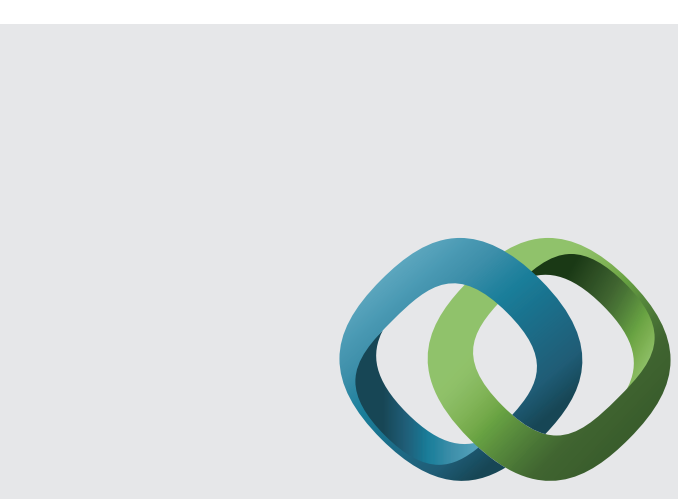

\section{Hindawi}

Submit your manuscripts at

http://www.hindawi.com
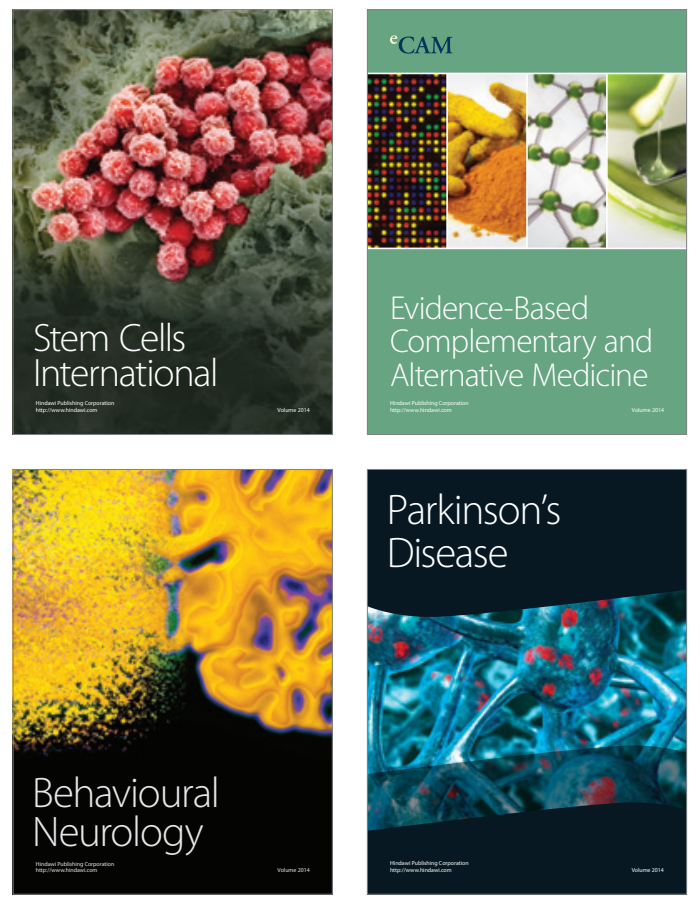
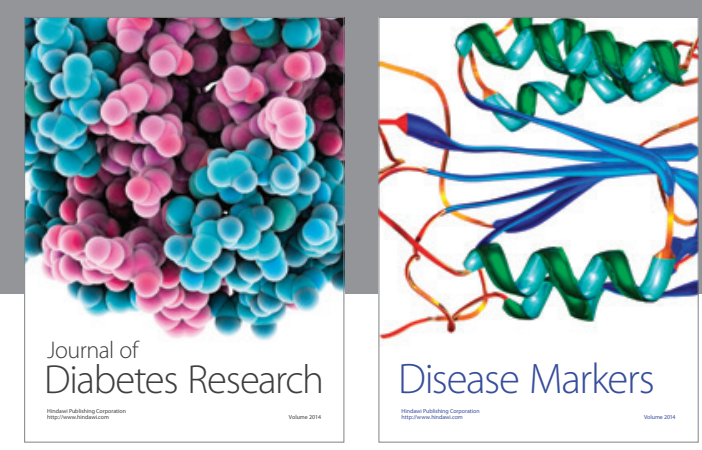

Disease Markers
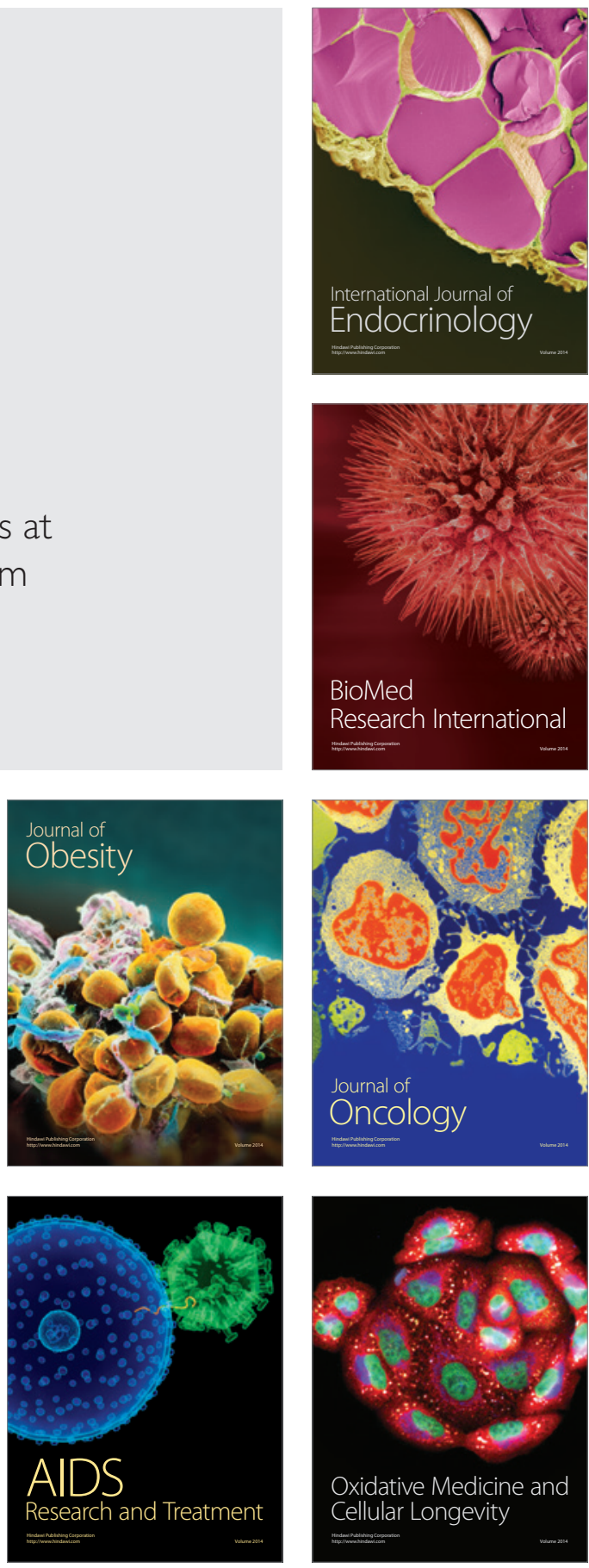